


\section{Barbara Peinstock Lectures on The fflorals of $\mathbb{T r a v e}$}

HIGHER EDUCATION AND BUSINESS STANDARDS. By WILLARD EUGENE НотснктSS.

CREATING CAPITAL: MONEY-MAKING AS AN AIM IN BUSINESS. BY FREDRRICK L. LIPMAN.

IS Civilization a disease? By StanTON CorT.

SOCIAL JUSTICE WITHOUT SOCIALISM. By John Batgs CLARK.

THE CONFLICT BETWEEN PRIYATE MONOPOLY AND GOOD CITIZENSHIP. By John Graham Brooks.

COMMERCIALISM AND JOURNALISM. BY HAMILTON HOLT.

THE BUSINESS CAREER IN ITS PUBLIC relations. By Albgrt Shaw. 


\section{CREATING CAPITAL MONEY-MAKING AS AN AIM IN BUSINESS}





\title{
CREATING CAPITAL MONEY-MAKING AS AN AIM IN BUSINESS
}

\author{
BY \\ FREDERICK L. LIPMAN
}

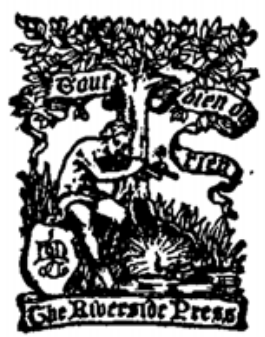

\author{
BOSTON AND NEW YORK \\ HOUGHTON MIFFLIN COMPANY

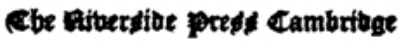

1918 
COPYRIGHT, 19I8, BY THE REGENTS OF THE UNIVERSITY OF CALIFORNIA

ALL RIGKTS RESERVED

Published Narch ror8

Rebe thiberdibe press

CAMBRIDGE - MASSACHUSETTS

$\mathbf{u} \cdot \mathbf{s} \cdot \mathbf{A}$ 